\title{
Post-fire recovery of a dense ombrophylous forest in Amazon
}

\section{DÁRLISON F.C. DE ANDRADE ${ }^{1,2}$, JOÃO R.V. GAMA², ADEMIR R. RUSCHEL ${ }^{3}$, LIA O. MELO $^{4}$, ANGELA L. DE AVILA ${ }^{5}$ and JOÃO O.P. DE CARVALHO ${ }^{6}$}

\author{
${ }^{1}$ Instituto Chico Mendes de Conservação da Biodiversidade/ICMBio, Floresta Nacional do \\ Tapajós, Av. Tapajós, 2201, Laguinho, 68040-000 Santarém, PA, Brazil \\ ${ }^{2}$ Programa de Pós-Graduação em Sociedade, Natureza e Desenvolvimento/PPGSND, Universidade Federal \\ do Oeste do Pará/UFOPA, Av. Mendonça Furtado, 2946, Fátima, 68040-470 Santarém, PA, Brazil \\ ${ }^{3}$ Embrapa Amazônia Oriental, Caixa Postal 48, 66095-100 Belém, PA, Brazil \\ ${ }^{4}$ Universidade Federal do Oeste do Pará/UFOPA, Instituto de Biodiversidade e Florestas/ \\ IBEF, Unidade Tapajós, Rua Vera Paz, s/n, Salé, 68035-110 Santarém, PA, Brazil \\ ${ }^{5}$ Forest Research Institute of Baden-Wuerttemberg/FVA, Department of Forest \\ Growth, Wonnhaldestraße 4, 79100, Freiburg, Germany \\ ${ }^{6}$ Universidade Federal Rural da Amazônia/UFRA, Travessa Pau Amarelo, s/n, \\ Vila Nova, Capitão Poço, 68650-000 Belém, PA, Brazil \\ Manuscript received on October 10, 2017; accepted for publication on August 28, 2018
}

\begin{abstract}
How to cite: DE ANDRADE DFC, GAMA JRV, RUSCHEL AR, MELO LO, DE AVILA AL AND CARVALHO JOP. 2019. Post-fire recovery of a dense ombrophylous forest in Amazon. An Acad Bras Cienc 91: e20170840. DOI 10.1590/0001-3765201920170840.
\end{abstract}

\begin{abstract}
The fires that occur in the Amazon are as damaging as the deforestation is. There is a need for further long-term studies on dynamics of tree communities in forests affected by fires. In the present study we evaluated the dynamics of tree species, before and after an accidental fire that occurred in 1997 in an experimental area of terra firme forest in the Floresta Nacional do Tapajós, in western Pará State, Brazil. Approximately 3500 trees with diameter measured at $1.30 \mathrm{~m}$ above ground (DBH) $\geq 5 \mathrm{~cm}$ were botanically identified and measured in 12 permanent plots of 0.25 ha (50 m x $50 \mathrm{~m})$, in 1983, 1987, 1989, 1995, 2008 and 2012. Analyses of survival, mortality and recruitment of trees were performed. The results showed that although the fire has increased the mortality and recruitment rates after 15 years, the highest mortality occurred on trees with smaller diameters $(\mathrm{DBH}<30 \mathrm{~cm}$ ), so the fire did not affect the survival of large trees in the long term, explaining why the reduction in density of living trees has not greatly influenced the decrease in basal area in the burned forest.
\end{abstract}

Key words: primary forest, tree mortality, post-fire dynamics, tree recruitment, resilience.

\section{INTRODUCTION}

The Amazon forest is a source of fascination for scientists (Correia et al. 2016), among them there is consensus that as greater is the knowledge of

Correspondence to: Dárlison Fernandes Carvalho de Andrade E-mail: darlisonicmbio@gmail.com ORCid: http://orcid.org/0000-0002-4362-8979 the dynamics and biological diversity as more efficient will be management, conservation and restoration actions of this biome (Silva et al. 2015). At the same time, the Amazon diversity also is the target of economic interests that, in recent decades, have contributed significantly to changes in the landscape of this territory (Nepstad et al. 2013). In addition to the deforestation that has led to the 
loss of environmental services (Fearnside 2006), recent studies have shown that degradation caused by selective logging without technical criteria, fires and others inappropriate anthropogenic uses are as damaging as deforestation, although only deforestation is monitored by the government (Barlow et al. 2016).

Moreover, it is likely that in this century, the Amazon will experience an increase in temperature, frequency and extent of drought events (Betts et al. 2016). Thus, forest fires may be increasingly recurrent (Barlow et al. 2016), considering that the leakage fire agricultural areas surrounding forests is threatening synergy between deforestation and climate change (Aragão et al. 2008), while little knowledge is available on the resilience of these forests to fire. The monitoring of burned forests is the best way to know the mechanisms of resilience after fire (Betts et al. 2016) and to describe the recovery path (Sato et al. 2016). The impact of forest fire is directly associated with tree mortality (Sato et al. 2016). The existing knowledge infers that, in fire-affected forests, mortality is directly proportional to the severity of the fire and after initial light burning, is higher in trees with smaller stems (Xaud et al. 2013).

However, most studies dealing with mortality after burning are based on short-term assessments - less than 2 years (Barlow et al. 2003). In the medium and long term, it is important to evaluate the survival of large and coarse-grained trees, considering that trees with more than $70 \mathrm{~cm}$ in diameter (Clark and Clark 1996), are resistant in the first years to fire impacts (Barlow et al. 2003).

The survival of large trees does not persist after severe fires, where all trees appear to become equally vulnerable (Barlow and Peres 2004). In addition to these questions about tree mortality after fire events, long-term studies for recruitment processes, including the survival of early recruits remain unknown (Bentos et al. 2017).
In this study, forest dynamics, considering survival, mortality and recruitment of trees, was monitored over 29 years (1983 - 2012), 14 years before and 15 years after fire. The monitoring was carried out in the Floresta Nacional do Tapajós. Permanent sample plots were installed - in a forest area with no history of selective timber extraction. In the present study it was intended to answer the following questions: (1) What was the effect of fire on mortality and recruitment of trees over 15 years after an accidental fire? (2) Was there any significant loss of basal area and density of trees due to fire? (3) What was the class of tree size most affected by fire?

Based on previous studies (Araujo et al. 2013, Barlow et al. 2003, Avila et al. 2017, Xaud et al. 2013), the first hypothesis of this study is that (1) the rates of mortality and recruitment of forest affected by fire were higher when compared to nonburned forest and (2) after 15 years, only the small trees were affected by the fire and the time elapsed after the fire was sufficient to have the losses in basal area and density of trees recovered.

\section{MATERIALS AND METHODS}

\section{AREA OF STUDY}

Approximately 527 thousand hectares are part of the Floresta Nacional do Tapajós, Federal Conservation Unit, located in the west of the State of Pará (Lat. $3^{\circ} 19^{\prime}$ S, Long: 5457’W, DATUM WGS 84), along the BR-163 (Andrade et al. 2015, Avila et al. 2017). The climate of the region, based on the data collected at the Belterra station (35 $\mathrm{km}$ north of Floresta Nacional do Tapajós), is hot and humid, with an annual average temperature of $26^{\circ} \mathrm{C}$, relative humidity of $87.30 \%$ and average of accumulated annual precipitation of $1780 \mathrm{~mm}$ (INMET 2017).

The study area is located in the plateau region of Floresta Nacional do Tapajós, near Km 114 of the BR-163. There are 36 hectares of forest, 
where 3 (three) plots were installed in 1983 in four continuous blocks of 9 (nine) hectares, totaling 12 sample units of 0.25 hectares $(50 \mathrm{~m} \times 50 \mathrm{~m})$, subdivided into 25 subplots of $10 \mathrm{~m} \times 10 \mathrm{~m}$, numbered from 1 to 25 to facilitate the location of the trees and control of the actions in the continuous sample inventories (Fig. 1).

The experimental area represents a typical dense ombrophylous forest of the region, with no history of forest exploitation (Carvalho 2002, Oliveira et al. 2005), characterized by the dominance of large arboreal individuals and by the abundance of woody lianas, palms and epiphytes, with a uniform canopy or with emergent trees (Gonçalves and Santos 2008).

The topography varies from flat to slightly undulating, with an approximate altitude of 175 $\mathrm{m}$ above sea level. The predominant soil is of the dystrophic yellow latosol type, medium to very clayey texture (Rodrigues et al. 2001, Vieira 1975).

The sampling area corresponds to the minimum number recommended to capture the heterogeneity of the site in research on the diversity and abundance of species in the forest (Bonar et al. 2011).

All trees $\mathrm{DBH} \geq 5 \mathrm{~cm}$ were measured in 1983 , 1987, 1989, 1995, 2008 and 2012, once each year, according to the methodology described in Silva et al. (2005). All trees were identified with numbered platelets (plot, subplot and tree number) to allow monitoring of their growth and survival rates over the years.

The species were identified in the forest with their vernacular names by parataxonomists. Those trees not identified in the forest had botanical material collected for later identification in the Embrapa Amazônia Oriental herbarium. The research was authorized by the Instituto Chico Mendes de Conservação da Biodiversidade (ICMBio), according to SISBIO Authorization No. $57419 / 2017$.

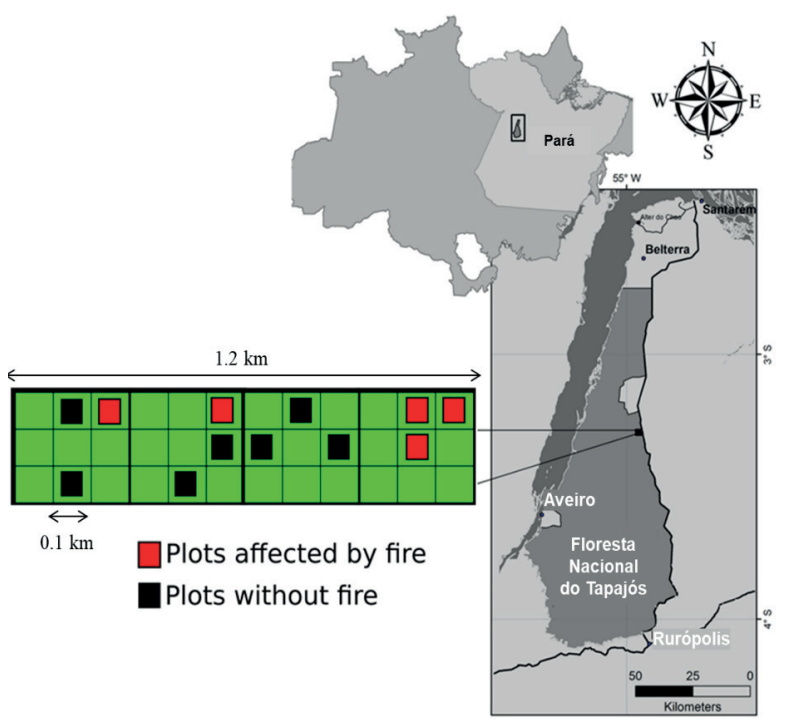

Figure 1 - Location of the T0 plots (black squares) and T1 (plots affected by fire), installed in an area of 36 hectares of dense ombrophylous forest, with no history of logging, in the Floresta Nacional do Tapajós, Pará State, Brazil.

\section{Forest Fire}

From December 9 to 13, 1997, an accidental fire burned a 1200-meter stretch of the Floresta Nacional do Tapajós, in the vicinity of Km 114 of the BR-163 Highway. The fire hit the vegetation very quickly and affected part of the permanent plots but it was put out by the Embrapa regional staff that worked during two days for minimizing the damage.

\section{DATA ANALYSIS}

The monitoring history of the area including the identification of the plots potentially affected by the fire (Avila et al. 2015, 2017, Oliveira et al. 2005, Sousa 1997) and data obtained in the measurements carried out in 1995 (before fire) and 2008 (after fire) were used for a quantitative analysis (descriptive statistics) with the mortality data (mean and standard deviation) and qualitative analysis of the species that entered in the tree community in that period, allowing the identification of a common pattern among the plots affected by fire. After this 
analysis, five fire-affected plots were, termed "T1" and seven "fire-free" plots were termed "T0".

The grouping of the plots made it possible to analyze the interaction between the ecological characteristics (recruitment rates - RR, mortality rates - MR, percentage of survival of remaining trees - SR, those recorded in the first measurement performed in 1983, basal area - BA - and density of trees - DA - and the explanatory variables (time and fire occurrence in 1997), comparing data from the different measurements performed in the plots, before and after fire, using the impact study method (Sit and Taylor 1998).

Those trees that reached or exceeded the minimum inclusion diameter of $5 \mathrm{~cm}(\mathrm{DBH} \geq 5 \mathrm{~cm})$ were considered "recruited" in each subsequent measurement. This value was divided by the number of years of the interval between measurements to obtain the number of recruits per hectare per year. From this value the annual percentage of recruits was calculated by the relation between the number of new trees in each measurement and the number of trees present in the previous measurement (Colpini et al. 2010).

"Dead" trees were considered those with $\mathrm{DBH} \geq 5 \mathrm{~cm}$ found dead in each measurement. The number of trees recorded as dead in each measurement was converted to the equivalent in hectares and divided by the number of years of the interval between the surveys to obtain the number of deaths in the period and then expressed hectare per year. From this value, as in the case of recruitments, the annual percentage of mortality was calculated by the ratio between the number of dead trees in each measurement and the total number of trees present in the previous measurement (Colpini et al. 2010).

The "remaining" trees were all trees recorded in the first measurement (1983) that remained alive in subsequent measurements. SR was calculated by the ratio between the number of remaining trees in each measurement and the total trees present in the first measurement. Graphical methods were used for evaluating the mortality of remaining trees, trees recruited and mortality by diameter class.

The BA was calculated by summing the sectional areas of each tree in each plot and then expressed in hectares according to the area sampled. The density of trees was calculated by the total number of trees per unit area, in this case, in hectares (Mueller-Dombois and Ellenberg 1974).

\section{Statistical Analysis}

The variables BA and DA were tabulated, considering $\mathrm{T} 0$ and $\mathrm{T} 1$ plots, for the seven measurements performed, as well as mortality and recruitment rates, among the five monitored periods (1983 - 1987, 1987 - 1989, 1989 - 1995, 1995 2008). In order to evaluate if the fire significantly affected the dynamics and structure of the forest, an ANOVA for repeated samples was applied, considering time as subdivided plots, due to the dependence between the multiple observations in the same sample units (Von Ende 1993).

To test the assumptions of the parametric analysis, the tests of normality of Shapiro-Wilk and homogeneity of variance of Bartlett were applied. The value of $\mathrm{F}$ was corrected using the Greenhouse-Geisser (G-G) or Huynh-Feldt (H-F) correction factors to infer on each variation source (Von Ende 1993).

We used the lowest factor (GG or HF) instead of the "F" value to test the hypotheses: null hypothesis ( $\mathrm{H} 0) \mu 1=\mu 2=\mu 3$ : that is, there is no significant difference between the variables analyzed (BA, Density, RR and MR) between the measurements or periods; Alternative hypothesis (H1) $\mu 1 \neq \mu 2 \neq \mu 3$ : there is at least one mean of the observed variables (BA, Density, MR and RR) different between measurements or periods.

All data were processed by the Tropical Forest Monitoring - MFT (software produced by Embrapa 
Amazônia Oriental) and later exported to Microsoft Office Excel 2016 for analysis.

\section{RESULTS}

In the year 1983, 3360 trees were inventoried, in a three hectare sample area. Over the 29 years of monitoring, 1588 trees were recorded as dead and 1495 new trees as recruited. In the 29-year period, in $\mathrm{T} 1$ plots $49.41 \%$ of the 1230 trees $^{-1}$ existing in 1983 died in 2012, corresponding to a mortality of 21.03 trees ha $^{-1}$ year $^{-1}$, while in the T0 plots $32.33 \%$ of $1041 \mathrm{ha}^{-1}$ trees died (11.64 trees ha ${ }^{-1}$ year $\left.^{-1}\right)$.

Only in the period from 1995 (2 years before fire) to 2008 (11 years after fire), in the T1 plots $27.50 \%$ of the remaining trees died, corresponding to 25.86 trees $^{-1} \mathrm{year}^{-1}$, while in $\mathrm{T} 0$ this percentage was $14.27 \%$ (11.36 trees $\mathrm{ha}^{-1}$ year $\left.^{-1}\right)$, in the same period. Before fire, the average mortality of remaining trees was 13.14 trees $\mathrm{ha}^{-1}$ year $^{-1}$, in T0, and 19.00 trees $^{-1} \mathrm{y}^{-1} \mathrm{year}^{-1}$ in T1, so there was a difference of 5.86 trees $^{-1} \mathrm{y}^{-1}$ year $^{-1}$ which made the number of trees increased to 11.86 trees $\mathrm{ha}^{-1}$ year $^{-1}$ after fire (Fig. 2a).

The percentage of survival of remaining trees (SR) in the last measurement in 2012 was $50.59 \%$ for $\mathrm{T} 1$ and $67.67 \%$ for $\mathrm{T} 0$, indicating a natural tendency for gradual replacement of older trees in both areas, intensified in the area affected by fire.

In the whole sample area, 239 trees that had been recruited after the first measurement were found died in the last measurement (29 years of monitoring), representing the number of 2.76 trees ha $^{-1}$ year ${ }^{-1}$, corresponding to $15.05 \%$ of the total trees dead in the study area. Before fire, the average mortality of recruited trees was 0.94 trees $^{-1} \mathrm{year}^{1}$ for T0 and 1.13 trees $\mathrm{ha}^{-1}$ year $^{-1}$ for $\mathrm{T} 1$, but the difference increased to 4.54 trees $\mathrm{ha}^{-1}$ year ${ }^{-1}$, after fire (Fig. 2b).

In $\mathrm{T} 1$ the increase in tree mortality after fire was compensated by the increase in the recruitment of new individuals (Fig. 2c) and, in the same way as it occurred with mortality rates, the recruitment rates of $\mathrm{T} 0$ and $\mathrm{T} 1$ distanced themselves after fire, indicating the role of the fire as an agent of changes in the forest dynamics, considering trees mortality and recruitment (Fig. 2d).

In the burned area (T1), there was a significant increase in mortality rates from 1995 to 2008 (F $=3.27, P$ value $=0.05$, Table $\mathrm{I})$ and a significant increase in recruitment rates from 2008 to 2012 (F $=5.01, P$ value $=0.03$, Table I). These were above the $2.5 \%$ range in the 29 years studied, being $2.77 \%$ and $2.99 \%$, respectively (Fig. 3a, b).

Before the fire (1983 - 1995), 92.54\% of the dead trees in $\mathrm{T} 1$ and $89.58 \%$ in $\mathrm{T} 0$ had diameters smaller than $30 \mathrm{~cm}$ (Fig. 4a). After fire, mortality rates of dead trees with $\mathrm{DBH}<30 \mathrm{~cm}$ increased to $94.58 \%$ in $\mathrm{T} 1$ and to $94.12 \%$ in $\mathrm{T} 0$ in the 1995 2008 period and remained high with $91.95 \%$ in $\mathrm{T} 1$ and $90.91 \%$ in T0 in the 2008 - 2012 period (Fig. $4 b, c)$.

All the trees recruited and recorded as dead had a DBH $\leq 20 \mathrm{~cm}$, so the period of 29 years was not enough to evaluate the mortality of trees recruited with larger diameters. Regarding the losses in basal area, in T1 plots there was an increase of $63.16 \%$ in loss of basal area for trees with DBH $<30 \mathrm{~cm}$ in the period from 1995 to 2008 (Fig. 4e), when it was compared to the period prior to the fire (1983 - 1995) (Fig. 4d), while in T0 there was a reduction of $7.14 \%$.

In the 2008 - 2012 period (Fig. 4f) there was a greater loss of large trees $(\mathrm{DBH}>60 \mathrm{~cm})$ in unburned plots (T0) (Fig. 4h), unlike T1 where few large trees died (Fig. 4c), indicating that, after 15 years, the fire had mainly affected trees of smaller size. In the period prior to the fire, the difference between the number of trees smaller than $30 \mathrm{~cm}$ that died in T1 and T0 was only 5.96 trees ha ${ }^{-1}$ year ${ }^{1}$ and became 12.24 trees $^{-1} \mathrm{y}^{-1}$ year $^{-1}$, which raised losses in basal area for trees smaller than 30 cm (Fig. 4g, h). 

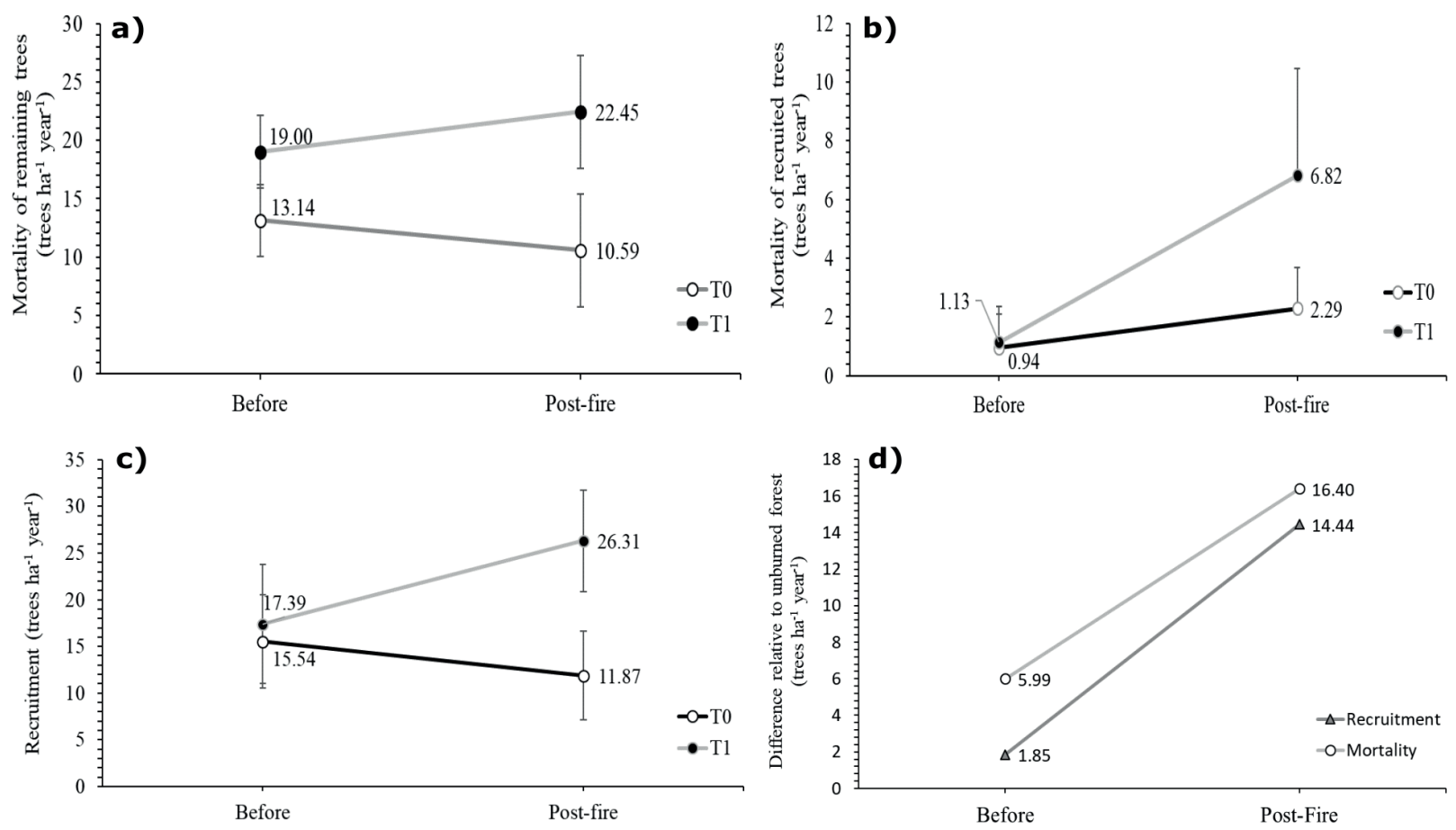

Figure 2 - Annual mortality rate (trees ha $^{-1}$ year $^{-1}$ ) for remaining trees (a) and trees recruited (b), annual recruitment rate (trees ha ${ }^{-1}$ year $\left.^{-1}\right)$ and (c) the difference between the mortality and recruitment rates recorded for T0 (1.75 ha) and T1 (1.25 ha), before and after fire (d), considering trees with $\mathrm{DBH} \geq 5 \mathrm{~cm}$, monitored during 29 years in an area of dense ombrophylous forest with no logging history in the Floresta Nacional do Tapajós, Pará State, Brazil.

TABLE I

Analysis of Variance (ANOVA) of repeated measurements of historical records (1983-2012) of density (trees ha ${ }^{-1}$ ), basal area $\left(\mathrm{m}^{2} \mathrm{ha}^{-1}\right)$, mortality rate $\left(\%\right.$ year $\left.{ }^{-1}\right)$ and recruitment rate $\left(\%\right.$ year $\left.{ }^{-1}\right)$ in T0 (no fire) and T1 (affected by fire, in 1997) plots, in an dense ombrophylous forest, with no history of logging, in the Floresta Nacional do Tapajós, Pará State, Brazil.

\begin{tabular}{|c|c|c|c|c|c|c|c|c|c|c|c|}
\hline & \multirow{2}{*}{$\begin{array}{l}\text { Source of } \\
\text { variation }\end{array}$} & \multicolumn{5}{|c|}{ Density (trees $\mathbf{h a}^{-1}$ ) } & \multicolumn{5}{|c|}{$\mathbf{B A}\left(\mathrm{m}^{2} \mathrm{ha}^{-1}\right)$} \\
\hline & & GL & $\mathbf{F}$ & $P$ value & G-G & H-F & GL & $\mathbf{F}$ & $P$ value & G-G & H-F \\
\hline \multirow{2}{*}{ T0 } & Time & 5 & 0.13 & 0.99 & 0.84 & 0.89 & 5 & 3.43 & 0.01 & 0.04 & 0.04 \\
\hline & Error & 20 & & & & & 20 & & & & \\
\hline \multirow{4}{*}{$\mathrm{T} 1$} & Time & 5 & 4.59 & 0.01 & 0.04 & 0.05 & 5 & 1.85 & 0.15 & 0.24 & 0.23 \\
\hline & Error & 20 & & & & & 20 & & & & \\
\hline & \multirow{2}{*}{$\begin{array}{l}\text { Source of } \\
\text { variation }\end{array}$} & \multicolumn{5}{|c|}{ MR (\%) } & \multicolumn{5}{|c|}{ RR (\%) } \\
\hline & & GL & $\mathbf{F}$ & $P$ value & G-G & H-F & GL & $\mathbf{F}$ & $P$ value & G-G & H-F \\
\hline \multirow{2}{*}{ T0 } & Time & 4 & 0.28 & 0.89 & 0.73 & 0.80 & 4 & 0.78 & 0.55 & 0.53 & 0.55 \\
\hline & Error & 24 & & & & & 24 & & \multirow{3}{*}{0.01} & \multirow{3}{*}{0.03} & \multirow{3}{*}{0.01} \\
\hline $\mathrm{T} 1$ & Time & 4 & 3.27 & 0.04 & 0.05 & 0.04 & 4 & 5.01 & & & \\
\hline 11 & Error & 16 & & & & & 16 & & & & \\
\hline
\end{tabular}



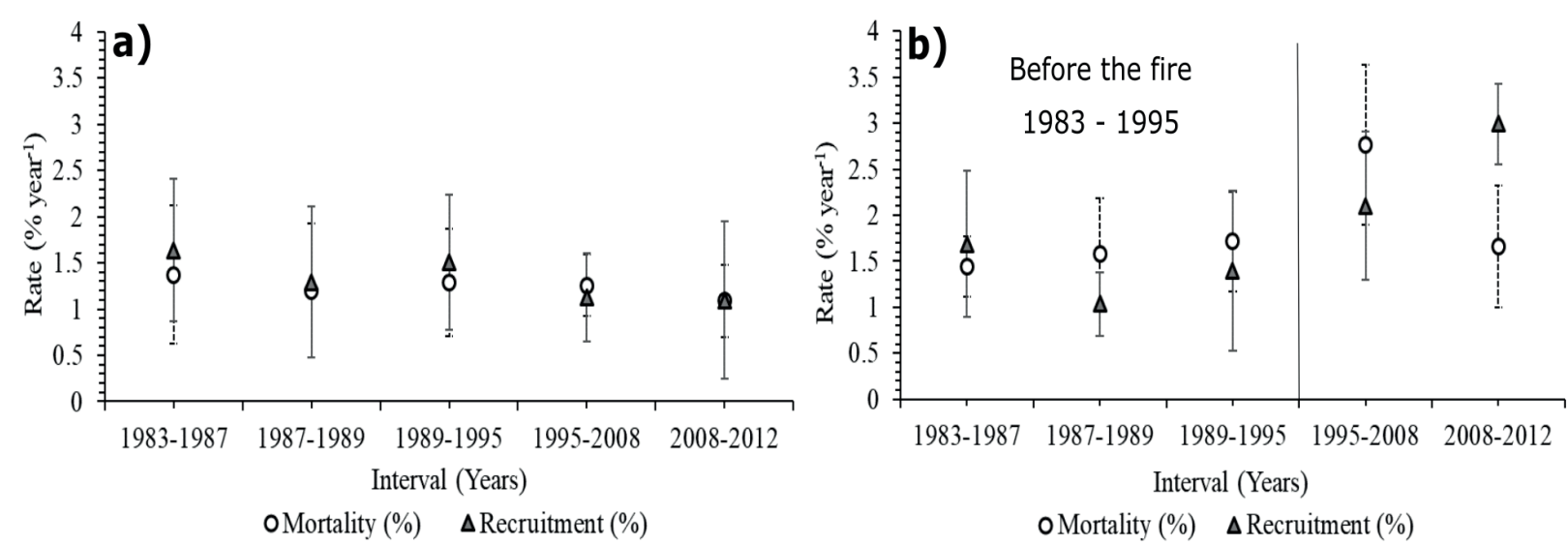

Figure 3 - Annual mortality and recruitment rates - percentage of recruited or killed trees compared to alive trees in the previous measurement, plus the respective standard deviation, for trees $\geq 5 \mathrm{~cm} \mathrm{DBH}$, in the T0 plots ( $1.75 \mathrm{ha})$, in a, and in the T1 plots ( 1.25 ha), in b, during 29 years of monitoring, in an dense ombrophylous forest, with no history of logging, in the Floresta Nacional do Tapajós, Pará State, Brazil.

The relationships between mortality and recruitment (Figs. 2 and 3) in the monitored periods were responsible for the positive or negative balances of tree abundance and basal area in the forest, before and after fire (Fig. 5).

In 29 years, there was little variation in the tree density (trees $\mathrm{ha}^{-1}$ ) for the $\mathrm{T} 0$ plots while in $\mathrm{T} 1$ plots a reduction, in density was observed after the fire $(\mathrm{F}=4.59, P$ value $=0.05$, Table I; Fig. 5a, b). In relation to basal area $\left(\mathrm{m}^{2} \mathrm{ha}^{-1}\right)$, the values obtained from the last measurement were the highest of the whole study period, in both $\mathrm{T} 1$ and $\mathrm{T} 0$, and there was therefore no fire effect in the reduction of basal area (Table I), although in T0 the forest stored more biomass in the 29 years of study $(\mathrm{F}=3.43, P$ value $=0.04$, Table I, Fig. 5c, d).

\section{DISCUSSION}

\section{MORTALITY AND RECRUITMENT}

The annual mortality and recruitment rates (Fig. 3), presented a characteristic pattern of native tropical forests, with no history of selective logging, with rates of 1 to 2\% per year (Fernandes et al. 2017, Souza et al. 2012), exception to recruitment rates recorded from 2008 to 2012 and mortality rates from 1995 to 2008 in T1 plots, where the mortality rate was similar to the standard found in a logged area in Floresta Nacional do Tapajós - 2.6\%, 2.4\% and $2.2 \%$ per year for five, six and eleven years after harvesting, respectively (Silva et al. 1995).

Mortality and recruitment should decrease with increasing census interval when obtained from censuses of non-homogeneous populations (Lewis et al. 2004). There is a tendency in the areas not affected by fire to decrease the mortality of the remaining trees, correlated to the monitoring period (Fig. 2), a pattern that diverged from the burned plots, where after the fire (2008) occurred the highest mortality (Table I, Figs. 2 and 3).

The stabilization in mortality rates and continued recruitment rates 15 years after fire is probably associated with the canopy opening caused by the mortality of remaining trees (Chazdon 2008), but it was expected that the effects of the changes that caused the increase in recruitment rates would be temporary and short-lived as observed in the studies of Avila et al. (2017).

After fire the mortality and recruitment rates recorded for $\mathrm{T} 1$ plots were relatively higher than in T0 plots (Fig. 3), and significantly higher when compared to the rates recorded in the same plots, in pre-fire years (Table I). In relation to the total number of dead trees in the entire community, 

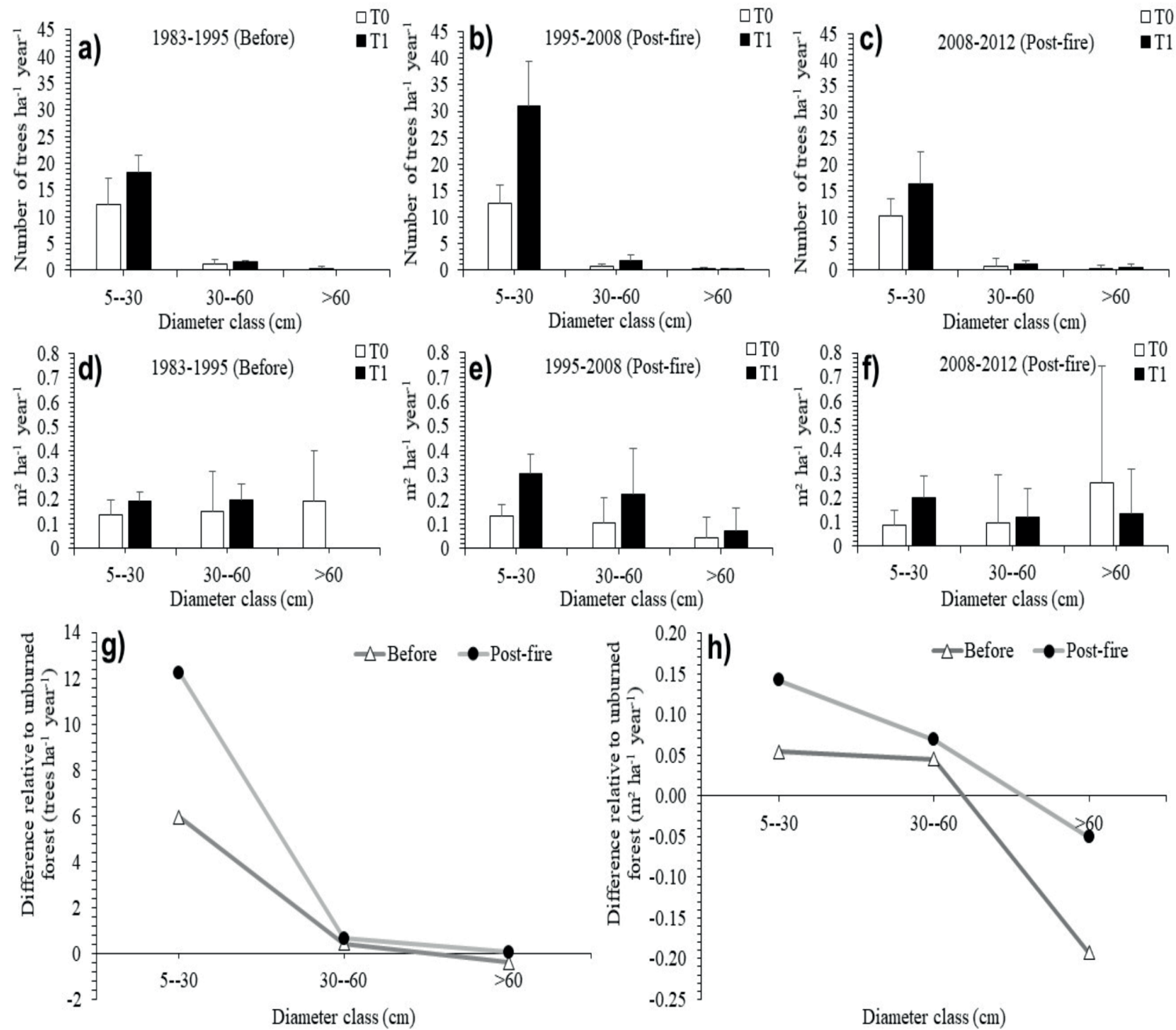

Figure 4 - Annual Mortality (trees ha $^{-1}$ year $^{-1}$ ) by diameter classes (cm), from 1983 to 1995 (a), 1995 to 2008 (b), 2008 to 2012 (c) and losses in basal area $\left(\mathrm{m}^{2} \mathrm{ha}^{-1}\right.$ year $\left.^{-1}\right)$, caused by tree mortality from 1983 to 1995 (d), 1995 to 2008 (e) and 2008 to 2012 (f), for burnt (T1) and unburned (T0) plots, and the difference between the mortality rates (g) and losses in basal area (h), by diameter class, recorded for the forest affected by fire in comparison to the forest not affected, before and after fire, in an dense ombrophylous forest, with no history of logging, in the Floresta Nacional do Tapajós, Pará State, Brazil.

the percentage of dead trees recruited was only $15.05 \%$, below the percentage of trees that had been recorded at the first measurement and that were dying over time (remaining) (Fig. 2).

In relation to the increase of the mortality of trees recruited in the $\mathrm{T} 1$ and $\mathrm{T} 0$ plots after fire, it is expected that as more are the trees registered as recruits, the greater will be the probability of death records for these trees. This type of monitoring should be carried out in the long term so that information on the survival of recruited trees should be known in longer time.

Recruit mortality $(\mathrm{DBH}<20 \mathrm{~cm}$ ) information plus the higher mortality of small remaining trees $(\mathrm{DBH}<30 \mathrm{~cm})$ may be a result, besides the direct effect of fire, of a greater competition caused by recruitment / densification of individuals, especially in canopy gaps generated by fire.

After fire, there was, therefore, a reduction in the abundance of trees $(P$ value $=0.05$, Table I $)$, 

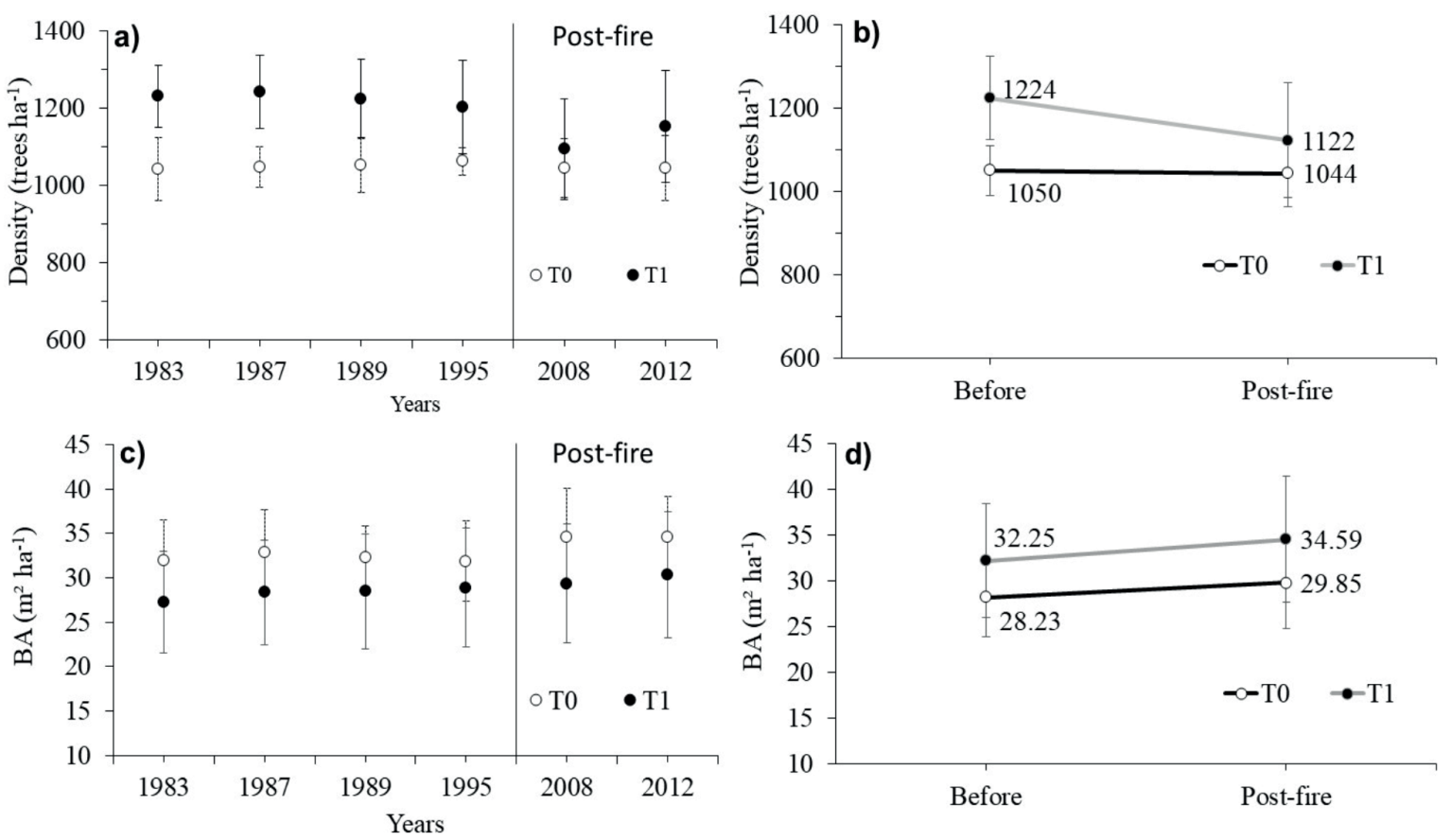

Figure 5 - Medium values of density (a) and difference between the means of density of before and after fire (b) and mean values of basal area (c) and difference between basal area averages before and after fire (d) in all measurements, in the 29 years of monitoring, for affected by fire (T1) and not affected by fire (T0) plots, in an dense ombrophylous forest, with no history of logging, in the Floresta Nacional do Tapajós, Pará State, Brazil.

mainly due to the higher mortality rates recorded for smaller trees $(\mathrm{DBH}<30 \mathrm{~cm})$, in which the competition was intensified.

The SR values recorded for both areas have shown that there is a gradual replacement of the remaining individuals in the forest strata over time, and fire seems to have accelerated this process, a characteristic that needs to be monitored in longer time intervals.

\section{FOREST RECOVERY}

The successional dynamics is driven by high mortality rates (Chazdon 2008) and the canopy opening caused by the death of large trees can play a fundamental role in the processes of changes in forest dynamics and structure (Clark and Clark 1996), a condition that was expected to be observed, after the occurrence of the fire (Barlow et al. 2003, Clark and Clark 1996).
However, in this study, before and after the occurrence of fire, the highest mortality occurred among trees with smaller diameters $(\mathrm{DBH}<30$ $\mathrm{cm}$ ) (Xaud et al. 2013) and the fire in the study area did not impact the survival of large trees (Sato et al. 2016), explaining why the reduction in the density of living trees (Barlow et al. 2003) did not strongly affect the decrease of the basal area in the burned forest.

The approach adopted here to investigate forest recovery was limited to mortality and recruitment rates as well as to changes in forest structural components - tree density and basal area. Among the observed variables, mortality and recruitment rates were useful to characterize the effects of fire on the dynamics of tree vegetation and were extremely sensitive to assess a stage of non-equilibrium in the forest.

Forests are dynamic ecosystems (Chazdon 2012) and complexes that after disturbances have 
ecologically organized processes of recovery to states prior to changes (Ghazoul et al. 2015). Postfire measurements showed a rapid forest recovery with high mortality rates shortly after fire, which were offset by high recruitment rates in the first post-fire decade and by the gradual decrease in mortality rates over time.

\section{CONCLUSIONS}

Fifteen years after fire, the forest affected by fire recovered in terms of mortality rate and still show high recruitment rates. The highest mortality occurred on trees with smaller diameters $(\mathrm{DBH}<30$ $\mathrm{cm})$ and the fire in the studied area did not impact the survival of large trees, explaining why the reduction in the density of living trees did not have a strong negative effect on the basal area in the forest burned.

\section{ACKNOWLEDGMENTS}

DFC Andrade thanks to the ICMBio for financial support during the PhD in UFOPA. We thank Embrapa Amazônia Oriental for the data transfer. DFC Andrade thanks graduate students and professors of the Instituto Nacional de Pesquisas da Amazônia (INPA) for assistance with statistical analysis and knowledge sharing.

\section{AUTHOR CONTRIBUTIONS}

DFC Andrade, JRV Gama and AR Ruschel are responsible for the study conception and sampling design and also contributed to the data analysis and to the writing of the manuscript. JOP Carvalho, LCO Melo and AL Avila are responsible to the writing of the manuscript with input from the other authors. All authors contributed to the interpretation of the results and provided critical feedback and contributed to the final version of the manuscript.

\section{REFERENCES}

ANDRADE DFC, GAMA JRV, MELO LO AND RUSCHEL AR. 2015. Inventário florestal de grandes áreas na Floresta
Nacional do Tapajós, Pará, Amazônia, Brasil. Biota Amaz 5(1): 109-115.

ARAGÃO LEOC, MALHI Y, BARBIER N, LIMA AA, SHIMABUKURO Y, ANDERSON L AND SAATCHI S. 2008. Interactions between rainfall, deforestation and fires during recent years in the Brazilian Amazonia. Phil trans R Soc Lond B 363(1498): 1779-1785.

ARAUJO HJB, OLIVEIRA LC, VASCONCELOS SS AND CORREIA MF. 2013. Danos provocados pelo fogo sobre a vegetação natural em uma floresta primária no estado do Acre, Amazônia Brasileira. Cienc Florest 23(2): 297-308.

AVILA AL, RUSCHEL AR, CARVALHO JOP, MAZZEI L, SILVA JNM, LOPES JC, ARAUJO MM, DORMANN CF AND BAUHUS J. 2015. Medium-term dynamics of tree species composition in response to silvicultural intervention intensities in a tropical rain forest. Biol Conserv 191: 577-586.

AVILA AL, SCHWARTZ G, RUSCHEL AR, LOPES JC, SILVA JNM, CARVALHO JOP, DORMANN CF, MAZZEI L, SOARES MHM AND BAUHUS J. 2017. Recruitment, growth and recovery of commercial tree species over 30 years following logging and thinning in a tropical rain forest. For Ecol Manage 385: 225-235.

BARLOW J ET AL. 2016. Anthropogenic disturbance in tropical forests can double biodiversity loss from deforestation. Nature 535(7610): 144-147.

BARLOW J AND PERES CA. 2004. Ecological responses to el Niño-induced surface fires in central Brazilian Amazonia: management implications for flammable tropical forests. Phil Trans R Soc Lond B 359: 367-380.

BARLOW J, PERES CA, LAGAN BO AND HAUGAASEN T. 2003. Large tree mortality and the decline of forest biomass following Amazonian wildfires. Ecol Lett 6(1): 6-8.

BENTOS TV, NASCIMENTO HEM, VIZCARRA MA AND WILLIAMSON GB. 2017. Effects of lightgaps and topography on Amazon secondary forest: Changes in species richness and community composition. For Ecol Manage 396: 124-131.

BETTS RA, MALHI Y AND ROBERTS JT. 2016. The future of the Amazon: new perspectives from climate, ecosystem and social sciences. Phil Trans R Soc Lond B 363(1498): 1729-1735.

BONAR S, FEHMI J AND MERCADO-SILVA N. 2011. An overview of sampling issues in species diversity and abundance surveys. In: Magurran BJ and Mcgill AE (Eds), Biological Diversity Frontiers in Measirement and Assessment. Oxford: Oxford University Press, England, p. 11-27.

CARVALHO JOP. 2002. Changes in the floristic composition of a terra firme rain forest in Brazilian Amazonia over an eight-year period in response to logging. Acta Amaz 32(2): 277-291.

CHAZDON RL. 2008. Chance and determinism in tropical forest succession. In: Carson WP and Schnitzer AS (Eds), Tropical Forest Community Ecology. United Kingdom: 
Wiley-Blackwell Publishing, Oxford, England, p. 384408.

CHAZDON RL. 2012. Regeneração de florestas tropicais. Bol do Mus Para Emílio Goeldi Ciências Nat 7(3): 195-218.

CLARK DB AND CLARK DA. 1996. Abundance, growth and mortality of very large trees in neotropical lowland rain forest. For Ecol Manage 80: 235-244

COLPINI C, SILVA VSM, SOARES TS, HIGUCHI N, TRAVAGIN DP AND ASSUMPÇÃO JVL. 2010. Incremento, ingresso e mortalidade em uma floresta de contato ombrófila aberta/estacional em Marcelândia, Estado do Mato Grosso. Acta Amaz 40(3): 549-555.

CORREIA RA, MALHADO ACM, LINS L, GAMARRA NC, BONFIM WAG, VALENCIA-AGUILAR A, BRAGAGNOLO C, JEPSON P AND LADLE RJ. 2016. The scientific value of Amazonian protected areas. Biodivers Conserv 25: 1503-1513.

FEARNSIDE PM. 2006. Desmatamento na Amazônia: dinâmica, impactos e controle. Acta Amaz 36(3): 395-400.

FERNANDES L, DIONISIO S, SCHWARTZ G, MAZZEI L, LOPES C, SANTOS GGA AND OLIVEIRA FA. 2017. Mortality of stocking commercial trees after reduced impact logging in eastern Amazonia. For Ecol Manage 401: 1-7.

GHAZOUL J, BURIVALOVA Z, GARCIA-ULLOA J AND KING LA. 2015. Review Conceptualizing Forest Degradation. Trends Ecol Evol 30(10): 622-632.

GONÇALVES FG AND SANTOS JR. 2008. Composição florística e estrutura de uma unidade de manejo florestal sustentável na Floresta Nacional do Tapajós, Pará. Acta Amaz 38(2): 229-244.

INMET - INSTITUTO NACIONAL DE METEOROLOGIA. 2017. Instituto Nacional de Meteorologia. Ministério da Agricultura, Pecuária e Abastecimento. Banco de Dados Meteorológicos para Ensino e Pesquisa. Disponível em: http://www.inmet.gov.br/portal/index.php?r=bdmep/ bdmep. Acesso em 19 de Outubro de 2017.

LEWIS SL ET AL. 2004. Tropical forest tree mortality, recruitment and turnover rates: calculation, interpretation and comparison when census intervals vary. J Ecol 92(6): 929-944.

MUELLER-DOMBOIS D AND ELLENBERG H. 1974. Aims and Methods of Vegetation Ecology. New York: J Wiley \& Sons, $547 \mathrm{p}$.

NEPSTAD D ET AL. 2013. More food, more forests, fewer emissions, better livelihoods: linking REDD+, sustainable supply chains and domestic policy in Brazil, Indonesia and Colombia. Carbon Manag 4(6): 639-658.

OLIVEIRALC, COUTO HTZ, SILVAJNMAND CARVALHO JOP. 2005. Efeito da exploração de madeira e tratamentos silviculturais na composição florística e diversidade de espécies em uma área de 136 ha na Floresta Nacional do Tapajós, Belterra. Sci For 69: 62-76.

RODRIGUES TE, SANTOS PL, OLIVEIRA JÚNIOR RC, VALENTE MAAND JÚNIOR EQC. 2001. Caracterização e classificação dos solos da área do planalto de Belterra, município de Santarém, PA. Embrapa Amazônia Oriental. Documentos 115.

SATO LY, GOMES VCF, SHIMABUKURO YE, KELLER M, ARAI E, SANTOS MN, BROWN IF AND ARAGÃO LEOC. 2016. Post-fire changes in forest biomass retrieved by airborne LiDAR in Amazonia. Remote Sens 8(10): $1-15$.

SILVA JNM, CARVALHO JOP, LOPES JCA, ALMEIDA BF, COSTA DHM, OLIVEIRA LC AND VANCLAY JK. 1995. Growth and yield of a tropical rain forest in the Brazilian Amazon 13 years after logging. For Ecol Manage 71: 267-274.

SILVA JNM, LOPES JDC, OLIVEIRA LC, SILVA SMA, CARVALHO JOP, COSTA DHM, MELO MS AND TAVARES MJM. 2005. Diretrizes para instalação e medição de parcelas permanentes em florestas naturais da Amazônia Brasileira. Embrapa Amazônia Oriental, Belém, Pará, 36 p.

SILVA KE, SOUZA CR, AZEVEDO CP AND ROSSI LMB. 2015. Dinâmica florestal estoque de carbono e fitossociologia de uma floresta densa de terra-firme na Amazônia Central. Sci For 43(105): 193-201.

SIT V AND TAYLOR B. 1998. Statistical methods for Adaptive Management Studies. In: Sit V and Taylor B (Eds), Land Management Handbook. Victoria: British Columbia Ministry of Forests Research Program 42: 148.

SOUSA LP. 1997. Queimadas no K 114, área de Manejo Florestal. Embrapa Amazônia Oriental, Belterra, Pará. Relatório de Ocorrência ${ }^{\circ} 106$.

SOUZA CR, AZEVEDO CP, ROSSI LMB, SILVA KE, SANTOS J AND HIGUCHI N. 2012. Dinâmica e estoque de carbono em floresta primária na região de Manaus/AM. Acta Amaz 42(4): 501-506.

VIEIRA LS. 1975. Levantamento de Recursos Naturais do Projeto Radam Brasil, Solos: folha SB.21. Rio de Janeiro: Departamento Nacional da Produção Mineral, p. 159-286.

VON ENDE CN. 1993. Repeated-Measures Analysis: Growth and Other Time Dependent Measures. In: Scheiner SM and Gurevitch J (Eds), Design and Analysis of Ecological Experiments. New York: Chapman \& Hall, New York, USA, p. 113-137.

XAUD HAM, MARTINS FSRV AND SANTOS JR. 2013. Tropical forest degradation by mega-fires in the northern Brazilian Amazon. For Ecol Manage 294: 97-106. 